\title{
COMO OBSERVAR MORAL E COSTUMES: requisitos filosóficos
}

\author{
Harriet Martineau*
}

Traduzido por Fábio Guimarães Liberal**

\section{Capítulo 1: requisitos filosóficos}

\begin{abstract}
Acredito apenas que isto não seja um arco que todo homem possa atirar, se assumindo um instrutor, mas exigirá tendões quase idênticos aos que Homero deu a Ulisses; ainda que eu esteja convencido de que pode ser bem mais fácil na tentativa do que parece agora à distância.
\end{abstract}

JOHN MILTON

Há duas partes no trabalho de observação da moral e dos costumes - o observador e o observado. Este é um fato importante cujo viajante raramente leva em consideração como deveria, contudo, uma breve reflexão revela que a mente do observador - o instrumento pelo qual o trabalho é realizado - é tão essencial quanto o material a ser trabalhado. Se o instrumento estiver fora de ordem, fornecerá um produto ruim, seja lá qual for o material em questão. Neste capítulo, mostrarei quais requisitos o viajante deve possuir antes de se comprometer a oferecer observações sobre a moral e os costumes de um povo.

\footnotetext{
* Pensadora britânica, hoje reconhecida como uma das primeiras sociólogas, ainda que suas ideias sejam pouco estudadas nos cursos de ciências sociais. Nasceu na Inglaterra em 1802, e morreu em 1876. É autora de mais de uma dezena de livros e milhares de artigos. O seu livro mais conhecido, talvez seja Society in America, publicado em 1837. É também reconhecida por seu trabalho de tradução da obra de August Comte - Curso de filosofia positiva.

** Doutor em sociologia pelo Programa de Pós-graduação em Sociologia (PPGS/UFPB/Brasil). E-mail: fabioliberal@hotmail.com.
} 


\section{Seção I}

Ele deve estar decidido sobre o que quer saber. $\mathrm{Na}$ ciência física, grandes resultados podem ser obtidos por experimentos aleatórios, mas esse não é o caso quando se trata da moral. Um químico dificilmente deixa de aprender algo ao juntar quaisquer substâncias sob novas circunstâncias e ver o que surgirá da combinação, e algumas descobertas importantes aconteceram dessa maneira na infância da ciência, embora ninguém duvide que mais conhecimento possa ser adquirido pelo químico que tem um objetivo em mente, e que conduz seu experimento embasado em algum princípio. Já no caso da moral, esse último método é o único que permite resultados úteis. No funcionamento do sistema social, grosso modo, todos os agentes são conhecidos — todos são determinados. Não é sua natureza, mas as proporções em que elas são combinadas, que devem ser verificadas.

O que o viajante quer saber? Ele está consciente de que, onde quer que vá, encontrará homens, mulheres e crianças; homens fortes e homens fracos; homens justos e homens egoístas. Ele sabe que em todos os lugares encontrará uma necessidade de comida, vestimenta e abrigo, e em toda parte, algum modo de acordo geral sobre como viver juntos. Ele sabe que em todos os lugares encontrará nascimento, casamento e morte, e, portanto, afetos domésticos. Quais resultados de todos esses elementos da vida social ele deseja procurar?

Por não resolver essa questão, um viajante deixa de enxergar verdadeiramente qualquer coisa, porque o estado das coisas não é consistente com suas especulações sobre como os seres humanos devem viver juntos; outro viajante vê o todo com preconceito, porque não se encaixa no que ele estava acostumado a ver em sua casa; todavia, cada um deles se retrairia com o reconhecimento de sua tolice, se esta fosse totalmente exposta diante dele. O primeiro teria vergonha de ter apreendido a comunidade existente por meio de um padrão arbitrário próprio - um ato muito parecido com o de sair para uma região selvagem para ver as casas dos reis cheias de homens em roupas leves; e o outro perceberia que nações diferentes podem continuar se julgando até o dia do juízo final, sem, de maneira alguma, melhorar as chances de progresso e entendimento mútuo. Sair com a desvantagem de um hábito mental sem controle intelectual nunca trará resultado. 
O viajante pode muito bem se conformar ficando em casa, embora nada venha a ganhar em relação a compreensão social.

As duas considerações que acabamos de mencionar devem estar subordinadas à questão maior - a única geral — da quantidade relativa de felicidade humana. Todo elemento da vida social extrai sua importância dessa grande consideração. As conveniências externas dos homens, suas emoções e afetos internos, seus arranjos sociais, ganham importância exatamente na proporção em que afetam a felicidade geral do segmento da raça na qual eles existem. Aqui, então, está o objetivo do sábio viajante manter sua visão excluída do preconceito, tanto filosófico quanto nacional. Ele não deve se permitir ficar perplexo ou enojado ao ver os grandes fins da associação humana perseguidos por meios que ele nunca poderia ter planejado, e cuja prática ele não poderia se reconciliar. Ele não deve concluir desfavoravelmente a respeito da dieta da multidão, porque os vê engolindo gorduras ou escavando melancias, em vez de se alegrarem com carne e cerveja. Ele não deve supor que suas reuniões sociais sejam um fracasso, porque eles comem com os dedos em vez de garfos de prata, ou tocam na testa em vez de fazer uma reverência. Ele não deve concluir contra a moral doméstica, devido a uma diversidade de métodos para conceber o casamento. Ele pode muito bem julgar as transações minuciosas dos costumes em todo o mundo pelo que vê em sua aldeia natal. Lá, deixar a porta aberta ou fechá-la não tem relação com a moral, e menos ainda com o costume; ao passo que fechar a porta é um ato tão cruel em uma cabana hindu quanto deixá-la aberta em uma cabana na Groenlândia. Em resumo, ele deve preparar-se para levar o que quer que possa observar a partir de algum princípio elevado e amplo, e não sob a perspectiva de uma comparação prática baixa. Julgar um povo, comparando-o com outro, é discutir dentro de um segmento muito pequeno de um círculo; e o observador só pode recuar e avançar a uma distância equivalente do nível da verdade. Testar a moral e os costumes de uma nação a partir de uma referência aos elementos essenciais da felicidade humana é atingir imediatamente o centro e ver as coisas como elas são.

\section{Seção II}

Provido de uma convicção do que quer saber, o viajante deve ainda estar guarnecido dos meios para obter o conhecimento desejado. Quando era criança, 
provavelmente lhe foi ensinado que olhos, ouvidos e compreensão são suficientes para se obter o máximo de conhecimento que o tempo lhe permitirá adquirir, mas sua autoeducação terá sido pobre, caso não tenha se convencido de que algo mais é necessário — a iluminação e disciplina do entendimento, bem como seu uso imediato. Não basta um viajante ter um entendimento ativo, equivalente a uma percepção precisa dos fatos individuais em si mesmos, ele deve também estar possuído de princípios que possam servir de ponto de partida para suas observações, e sem os quais ele não pode determinar o rumo delas, ou estar seguro de fazer uma interpretação correta acerca do observado. Um viajante pode se sair melhor sem olhos ou ouvidos do que sem esses princípios, como há evidências que comprovam. Holman, o viajante cego, obtém uma quantidade maravilhosa de informações, embora esteja impedido de enxergar as evidências produzidas pelo semblante humano, pelos grupos que o margeiam, pelo aspecto das cidades e pelos fenômenos variados das regiões do país. No seu mote, ele indica algo do seu método.

Sem visão para ver e julgar através do julgamento dos olhos,

Fazer quatro sentidos realizar o trabalho de cinco,

Munir a mente para uma aventura esperançosa,

São luzes para quem vive na escuridão.

Para "julgar por meio do julgamento dos olhos", esses olhos devem ser fortes e claros, e um viajante pode ganhar mais com a falta do órgão corporal do que com um entendimento destreinado. O caso do viajante surdo nos leva a dizer o mesmo sobre a outra grande via de conhecimento. Seus escritos provam, para todos que os conhecem, que, embora em grande parte privado da inestimável narrativa acerca dos fatos percebidos - o discurso humano - o Viajante Surdo é capaz de nos fornecer mais conhecimento sobre pessoas estrangeiras do que o próprio Ouvinte sem os acompanhamentos do poder analítico e do pensamento concentrado. Todos os sentidos, poderes intelectuais e bons hábitos podem ser considerados essenciais para uma observação da moral e dos costumes perfeita; mas quase qualquer um pode ser poupado de uma provisão de princípios que possa servir como um ponto de convergência e uma prova dos fatos. Os viajantes cegos e surdos sofrem de uma privação ou deficiência de certas categorias de fatos. A condição do viajante não filosófico é muito pior. É um acaso se ele chega a uma interpretação correta em qualquer um dos fatos que percebe. 
Muitos podem objetar que neste trabalho estou transformando em assunto sério demais o negócio da viagem. Eles não pretendem ser filósofos morais, eles não desejam ser oráculos, eles tentam apenas dar um simples relato daquilo que foi notado. Mas que trabalho na Terra é mais sério do que este de relatar as coisas mais graves e importantes que são realizadas neste mundo? Todo relato verdadeiro é um grande bem; todo relato falso é um grande mal. Portanto, que não haja relato algum dado, a não ser por pessoas com algum grau de qualificação. Aqueles viajantes que não se esforçarem para obter o pensamento e estudo requisitados devem se abster de relatar.

No entanto, é um erro supor que o estudo considerado necessário seja vasto e profundo. Algum conhecimento dos princípios da Moral e das regras dos Costumes é necessário, assim como de outras ciências em ocasiões particulares; mas os princípios são poucos e simples, e a regra de aplicação fácil.

O resumo das noções universais da Moral pode servir a um viajante comum em seus julgamentos sobre se ele gostaria de viver em algum país estrangeiro, e se as pessoas de lá são tão agradáveis para ele quanto as de sua própria nação. Para alguém assim, parece suficiente assumir que as noções gerais de mentira, roubo, ociosidade e libertinagem são ruins; e de verdade, honestidade, diligência e sobriedade são boas; e a partir de propósitos comuns, poderíamos confiar nesse alguém para emitir o que vem a ser diligência e ociosidade; o que é libertinagem e sobriedade. Porém noções vagas e preconcepções domésticas, mesmo nesses grandes temas da moral, não são suficientes aos olhos de um viajante esclarecido para garantir decisões sobre o estado moral das nações, forjadas em uma ampla diversidade de circunstâncias.

A verdadeira liberalidade, que por si só é digna de contemplar todas as nações da terra, não traça uma linha rígida no meio da conduta humana, fixando tudo o que recai sobre o vício de um lado e sobre a virtude do outro; tal liberalidade sabe que ações e hábitos nem sempre transmitem sua impressão moral de modo visível a todos os olhos, e que o caráter de muitos deve ser determinado por uma aplicação cautelosa de alguns princípios profundos. Os Shaker ${ }^{1}$ da Nova Inglaterra sãao um bom juiz da moral e dos

\footnotetext{
${ }^{1}$ Seita protestante instituída na Inglaterra do século XVIII, cuja origem remete à dissidência de uma comunidade Quaker. Se destaca pelo fervor dos integrantes durante os cultos e pelo protagonismo feminino na sua estrutura organizacional. Todas as notas foram acrescentadas pelo tradutor.
} 
costumes dos árabes do deserto? Que tipo de veredicto o cigano mais astuto daria sobre o monge de La Trappe ${ }^{2}$. O que o camponês escocês pensaria das práticas mágicas do Egito? Ou o soldado russo acerca de uma reunião de eleitores nos Estados Unidos? As ideias de certo e errado nas mentes dessas pessoas não são do tipo ampliado, o que lhes permitiria julgar as pessoas em situações mais opostas às suas. O verdadeiro filósofo, o digno observador, primeiro contempla na imaginação a extensão da humanidade e depois verifica quais princípios morais são aplicáveis a toda ela, e julga a partir desses juízos.

O viajante iluminado, se ele explora apenas um país, carrega em sua mente a imagem de todos, pois apenas em sua relação com toda a raça, uma pessoa pode ser julgada. Quase sem exagero, pode-se dizer que ele vê o que o rapsodista de Volney ${ }^{3}$ viu.

Lá, de cima da atmosfera, olhando para a terra que eu tinha deixado, contemplei uma cena inteiramente nova. Sob meus pés, flutuando no espaço vazio, um globo semelhante ao da lua, mas menos luminoso, me apresentou uma de suas faces .... "O que!" exclamei eu: "é aquela a terra habitada por seres humanos?"

As diferenças são que, em vez de "uma de suas faces", o moralista enxergaria a terra inteira em contemplação; e que, em vez de uma extensão nebulosa aqui e uma mancha marrom ou cinza ali - continentes, mares ou vulcões - ele examinaria os lares e as assembleias sociais de todas as terras. No extremo norte, há a cabana de neve dos Esquimós, brilhando com o fogo interno, como uma lâmpada de alabastro queimando num espaço enorme; lá dentro, o pai com a barba por fazer conserta suas armas feitas de espinhas de peixe, enquanto a mãe anã envolve seu bebê em peles e o alimenta com óleo e gordura. No extremo leste, há a família chinesa em seu jardim, pisando nas calçadas pavimentadas ou sentadas à sombra de suas rochas artificiais; o mestre mostra as garras da mão esquerda enquanto fuma o cachimbo, e a esposa cambaleia sob os pés deformados enquanto segue o filho - exultante, pois é ele um menino; grave e cheia de lamentação, caso a providência tivesse enviado apenas meninas. No extremo sul, há o colonizador do Cabo, descansando-se preguiçosamente diante de sua porta, enquanto envia seu

\footnotetext{
${ }^{2} \mathrm{O}$ mosteiro La Trappe está situado no sul da Holanda, cujos monges ficaram conhecidos pela produção de cerveja.

${ }^{3}$ Constantin-François de Chasseboeuf, o conde de Volney — nascido em 3 de fevereiro de 1757 em Craon, França, e falecido em 25 de abril de 1820, em Paris — foi um historiador e filósofo cuja obra Les Ruines, ou méditations sur les révolutions des empires propôs uma compilação do pensamento histórico e político racionalista do século XVIII. É dessa obra que provém a citação em pauta.
} 
trabalhador para longe com seu carro de boi; repassa o expediente agrícola às mulheres, de maneira que intimida da sua porta um pobre hotentote ${ }^{4}$ que teria vagado por esta planície. No extremo oeste, há uma reunião na costa do Pacífico de caçadores abarrotados de peles. Os homens estão negociando, limpando suas armas ou dormindo; as mulheres cozinhando ou tingindo com sucos de vegetais os espinhos de porco-espinho ou os pelos de alce. Nos intervalos dessas atividades, existe um mundo de costumes tão diverso quanto à superfície das terras onde são exibidos. Aqui está o nobre russo em sua propriedade, o senhor do destino de seus servos, mas pressionado pela inimizade de nobres rivais e silenciado pelo despotismo de seu príncipe; sua esposa leva uma vida lânguida entre suas donzelas tecendo; e seus filhos pequenos falam das guerras por vir em que servirão seu imperador. Há o comerciante de Frankfurt, vivendo entre iguais, concentrando seu orgulho em não ter prejudicado ninguém, ou em ter um filho distinto frequentando a universidade, ou uma filha habilidosa em realizações domésticas; enquanto a esposa emula os vizinhos por apoiar o conforto e a respeitabilidade da família. Aqui está o camponês francês que volta do campo em completa ignorância acerca do que aconteceu na capital nos últimos tempos; e há o artesão inglês discutindo sua política da cidade com seu irmão trabalhador ou levando para casa alguma nova esperança de interferência parlamentar no trabalho e nos salários. Aqui está um conclave de cardeais, consultando os interesses da Santa Sé; ali, um grupo de Brâmanes coloca uma oferta de arroz diante de seu ídolo. Em uma direção, há um punhado de cidadãos construindo uma nova cidade no meio de uma floresta; em outra, há uma tropa de cavaleiros pairando no horizonte, enquanto uma caravana está atravessando o deserto. Sob as sombras cintilantes de uma vinha alemã, canções nacionais são cantaroladas; dos lugares íngremes das montanhas suíças ressoa a trompa dos Alpes; no café do Cairo, os ouvintes se apegam à voz do recitador do romance; das igrejas da Itália ecoam hinos solenes; e os tons suaves da criança são ouvidos no salão da Nova Inglaterra, enquanto o jovem estudioso lê a Bíblia para um velho pai ou avô.

Tudo isso, e muito mais, irá considerar, por meio dos olhos de sua mente, um viajante da mais esclarecida ordem enquanto observa os grupos que são apresentados a

\footnotetext{
${ }^{4} \mathrm{O}$ termo era usado pelos colonos holandeses, que ocuparam a Cidade do Cabo no século XVII, para se referir aos Khoikhoi, grupo indígena não-Bantu de nômades pastores.
} 
seus sentidos. Mas há poucos viajantes desse tipo; e noções vagas e gerais, ou meramente tradicionais, de certo e errado servirão ao propósito de um número maior. O principal mal das noções morais, sejam elas vagas ou tradicionais, é que elas são inconciliáveis com a liberalidade do julgamento, e o grande benefício de uma certificação dos princípios básicos da moral é que a investigação dissolve o preconceito e lança uma luz completa sobre muitas coisas que deixam de ser assustadoras e dolorosas quando deixam de ser obscuras. Todos sabemos como um domingo em Paris parece diferente a um sectário, para quem a palavra de seu padre é lei; e a um filósofo, para quem a religião é indígena, pois entende a estreiteza das seitas, e vê o quão menor o próprio Cristianismo é se comparado a humanidade. Todos sabemos o poder ofensivo das orações dos Maometanos nas esquinas das ruas e a pompa das procissões católicas, para aqueles que não conhecem outra maneira senão entrar em seu armário e fechar a porta quando oram; mas como se sentiu o pensador profundo que escreveu a Religio Medici? Ele era um membro ordenado de uma igreja Protestante, mas mesmo assim prestasse reverencia com a cabeça frente à imagem de um crucifixo; não podia rir dos peregrinos andando com ervilhas nos sapatos, nem desprezar um frade implorador; ele "não podia ouvir um sino da Ave Maria sem uma elevação"; e é provável que mesmo os terafins dos árabes não fossem totalmente absurdos, ou o carro de Juggernaut ${ }^{5}$ totalmente odioso aos olhos dele. Este é o contraste entre o sectário e o filósofo.

\section{Seção III}

Como exemplo da vantagem que um viajante filosófico possui sobre um despreparado, observe a diferença de julgamento das nações feita por um homem; se de acordo com uma vaga noção popular de senso moral que ele carrega consigo, ou com base na investigação das leis sob as quais os sentimentos de certo e errado crescem em todos os homens. Vale a pena se deter um pouco nesse importante aspecto.

A maioria das pessoas que precisam se esforçar muito para pensar por si mesmas tem uma noção de que todo ser humano tem sentimentos, ou uma consciência, nascida com ele, por meio da qual ele sabe, apenas atendendo a ela, exatamente o que é certo e

\footnotetext{
5 Juggernaut faz referência ao carro Ratha Yatra, da cultura hindu, sob o qual muitos devotos se jogavam para serem esmagados por suas rodas com a certeza de que tal morte lhes traria a salvação.
} 
errado; e que, como o certo e errado são fixos e imutáveis, todos devem concordar com o que é pecado e virtude em todos os casos. No entanto, a humanidade está, e sempre esteve, tão longe da concordância em relação ao certo e ao errado, que é necessário demonstrar de alguma maneira as amplas diferenças em várias eras e entre várias nações. Uma grande diversidade de doutrinas foi apresentada com o objetivo de diminuir a dificuldade, mas todas extraem de sua totalidade certos aspectos da raça para condenação ou compaixão seja por erro, cegueira ou pecado. Além disso, nenhuma doutrina ainda inventada foi responsável por revoluções totais nas ideias de certo e errado, que tenham ocorrido ao longo do tempo. Uma pessoa que assume como certo que existe um senso moral universal entre os homens, tão imutável quanto quem o concebeu, não pode explicar razoavelmente como aqueles homens que eram considerados os mais virtuosos por terem matado mais inimigos em batalha, encontram agora um contexto no qual se considera muito mais nobre salvar vidas do que destruí-las. Eles não podem deixar de se perguntar como era uma vergonha enorme viver na miséria e uma honra cometer suicídio; enquanto agora os homens mais sábios e melhores pensam exatamente o contrário. E, com relação a era atual, ela deve intrigar os homens que supõem que todos devam pensar da mesma forma em assuntos morais, já que há partes do mundo em que as mães acreditam que é um dever afogar seus filhos, e que os magnatas orientais zombam abertamente do rei da Inglaterra por ter apenas uma esposa em vez de cem. Não há como evitar a iliberalidade, segundo essa crença - na medida em que o filósofo tem a compreensão da iliberalidade. Não há como evitar a conclusão de que as pessoas que praticam infanticídio e poligamia são desesperadamente perversas, e que pequenas diferenças de conduta são, seja no exterior ou em casa, nada menos que pecados.

O observador que parte com uma crença mais filosófica, não apenas escapa da aflição de enxergar pecado onde quer que haja diferença, como também evita o sofrimento gerado pelo desprezo e alienação de sua espécie, estando, pelo contrário, preparado para o que testemunha, e ciente das causas, livre da agitação de ficar chocado e alarmado, preserva sua calma, sua esperança, sua simpatia, e, portanto, está muito mais preparado para perceber, entender e relatar a moral e os costumes das pessoas que visita. Sua crença mais filosófica, derivada de todas as evidências e reflexões justas, é que os sentimentos de certo e errado de todo homem, em vez de nascer com ele, crescem nele das influências a que ele está sujeito. Vemos que em outros casos — no que diz respeito à ciência, à arte 
e às aparências da natureza — os sentimentos surgem do conhecimento e da experiência, e há toda evidência de que o mesmo acontece com relação a moral. Os sentimentos começam muito cedo, e esta é a razão pela qual eles parecem ter nascido com os homens, mas eles são poucos e imperfeitos na infância e, mesmo aqueles que são fortemente vinculados à moral, continuam ampliando, fortalecendo-se e se aperfeiçoando ao longo da vida. Veja o efeito nas observações do viajante que mantém essa crença sobre a consciência! Sabendo que algumas influências agem sobre todas as pessoas em todos os países, ele procura em todo lugar certos sentimentos de certo e errado que são evidentes na mente de todos os homens como se tivessem nascido com eles. Por exemplo, atormentar alguém sem qualquer motivo, real ou imaginário, é considerado errado em todo o mundo. Do mesmo modo, fazer os outros felizes é universalmente considerado correto. Ao mesmo tempo, o viajante está preparado para encontrar uma variedade infinita de diferenças em assuntos menores e fica aliviado com a necessidade de declarar que cada um é um vício em um ou outro aspecto. Sua própria educação moral, tendo sido mais elevada e avançada do que a de algumas pessoas que ele venha a contemplar, não o faz deixar de sentir tristeza e desgosto por várias coisas que ele testemunha, mas é a ignorância e a barbárie que ele lamenta, e não o vício. Quando ele vê o índio árabe ou americano oferecer a filha ou esposa ao estrangeiro, como parte da hospitalidade que, na mente do anfitrião, é seu primeiro dever, o observador considera o fato do mesmo modo que julga o modelo de educação da velha Esparta, onde dureza física e escravidão moral constituíam um homem muito honrado. Se ele vir um estudante americano gastando toda a sua pequena fortuna, saindo da faculdade, viajando pela Europa, ele não o culpará, como culparia um jovem inglês por fazer a mesma coisa. $\mathrm{O}$ inglês seria um gastador, $\mathrm{o}$ americano um sábio: e a razão é que suas circunstâncias, perspectivas e, portanto, suas visões de dever são diferentes. $\mathrm{O}$ americano, tendo a certeza de obter uma manutenção independente, pode fazer com que o alargamento de sua mente e o cultivo de seus gostos por viagens seja seu primeiro objetivo, enquanto o inglês consciente deve cumprir as difíceis condições de independência antes de poder viajar. O capital é para ele um dos principais requisitos da independência honesta, enquanto para o americano não é de todo necessário. Ficar sem roupa era, até recentemente, perfeitamente inocente nas Ilhas do Mar do Sul, mas agora que a civilização foi razoavelmente estabelecida pelos missionários, tornou-se um pecado. Deixar um inimigo escapar com vida é uma desgraça 
em alguns países do mundo, enquanto em outros é mais honroso perdoar do que puni-lo. A variedade de tais instâncias e oposições de consciência podem ser multiplicadas num grande volume, para a perplexidade e tristeza do observador não-filosófico e a serena instrução do filosófico.

As influências gerais sob as quais ideias universais e sentimentos de certo e errado são formadas são dispensadas pela Providência por meio da qual todos são educados. Que a intenção do Criador é tão evidentemente a felicidade do homem, e os artifícios para esse fim são tão numerosos e impressionantes, que a percepção desse intuito pode ser chamada de universal. Tudo o que tende a tornar os homens felizes, torna-se um cumprimento da vontade de Deus. Tudo o que tende a torná-los infelizes se torna oposição à sua vontade. Há, e deve haver, uma série de obstáculos ao reconhecimento expresso e à obediência prática desses grandes princípios, mas eles podem ser descobertos em todos os países com base na religião e na moral. Existem impedimentos da ignorância, e erro consequente, egoísmo, e paixão: os homens mais infantis confundem os meios da felicidade humana, e os mais sábios têm apenas uma percepção fraca e flutuante deles, mas todos os homens mantêm uma convicção comum, que o que faz as pessoas felizes é o bom e o certo, e que o que as torna infelizes é o mal e o errado. Essa convicção está no fundo de práticas que carregam consigo a maior inconsistência. Quando o Axante $^{6}$ oferece um sacrifício humano, é para garantir as bênçãos de seus deuses. Quando o hindu expõe seu pai doente no Ganges, ele acha que está extraindo sua dor por meio de uma morte encantada. Quando Sand esfaqueou Kotzebue ${ }^{7}$, ele acreditava que estava punindo e se livrando de um inimigo e um empecilho ao bem-estar de sua nação. Quando o plantador georgiano compra e vende escravos, ele supõe que está preservando a ordem e a subordinação devida da sociedade. Todas essas noções são mostradas pela filosofia como estreitas, superficiais e equivocadas. Elas foram superadas por muitos e, sem dúvida, estão destinadas a serem superadas por todos, mas, praticada pelos ignorantes e iludidos, elas são muito distintas da maldade que aflige o melhor conhecimento. No entanto, essas práticas seriam maldade, perpetrada contra um melhor conhecimento, se fosse verdadeira a suposição de um Senso

\footnotetext{
${ }^{6}$ Os Axantes ou Axântis são um dos principais grupos étnicos de Gana. Antes da colonização europeia, formaram um poderoso império na África Ocidental.

${ }^{7}$ Karl Ludwig Sand foi um jovem estudante da Universidade de Jena. Em 1819, ele foi sorteado em uma sessão da Burschenschaft (uma forma tradicional de sociedade estudantil alemã) para executar o escritor e dramaturgo, August von Kotzebue.
} 
Moral universal e infalível. O viajante que sempre adere à noção de Senso Moral deve declarar o adorador Axante tão culpado quanto Greenacre: o filho hindu, um parricida, no sentido mais revoltante do termo; um Sand ou um Thurtell ${ }^{8}$; e o fazendeiro georgiano um monstro tão tirano quanto um fazendeiro de Sussex seria se montasse um posto de açoitamento para seus trabalhadores, e vendesse os filhos deles para os ciganos. Tais julgamentos seriam cruelmente iliberais. $\mathrm{O}$ viajante equipado com a filosofia mais precisa da consciência chegaria a conclusões, não apenas mais corretas, mas muito menos dolorosas, e, sem qualquer negligência de princípios, muito mais generosas.

Há tanta coisa para demonstrar a vantagem do viajante possuidor de princípios definidos, para ser usado como referência e testar suas observações, em vez de utilizar noções morais vagas e pressuposições gerais, que apenas servem como uma trilha falsa, pela qual muito do que ele vê torna-se necessariamente pervertido ou obscurecido.

\section{Seção IV}

O viajante, uma vez convencido de que existem alguns sentimentos universais sobre certo e errado, e que, consequentemente, alguns aspectos da conduta humana são guiados por regras gerais, deve, em seguida, voltar sua atenção aos modos de conduta que lhe parecem bons ou ruins, e que predominam em uma nação, distrito ou sociedade de dimensões mais reduzidos. Seu princípio geral inicial é que a lei da natureza é a única pela qual a humanidade como um todo pode ser julgada. O segundo deve ser que toda virtude ou vício predominante é o resultado de circunstâncias particulares nas quais a sociedade existe.

As circunstâncias nas quais uma virtude ou vício predominante se originam podem ou não ser rastreáveis por um viajante. Se possível, ele não deve buscar se familiarizar com todo o caso. Se obscuro, ele deve tomar cuidado com a imputação de desgraças aos indivíduos, como se esses indivíduos estivessem vivendo sob as influências que o fizeram se tornar o que ele é. Ele não culpará uma deficiência de independência moral em um cidadão da Filadélfia tão severamente quanto em um cidadão de Londres;

\footnotetext{
${ }^{8}$ Em 1823, num condado do sul da Inglaterra, John Thurtell assassinou brutalmente William Weare, e o corpo foi descartado num lago. O crime teve enorme repercussão na época e foi objeto de inúmeros livros e peças de teatro.
} 
vendo, como ele deve ser, que a falta de independência moral é uma falha predominante nos Estados Unidos e que deve haver alguma razão para isso. Mais uma vez, ele não procurará no camponês polonês a inteligência política, a atividade e os princípios que o encantam na casa de toras do fazendeiro americano. Ele percebe que os camponeses poloneses são geralmente passivos, e os agricultores americanos comumente se interessam por política, e que deve haver razões para essa diferença.

$\mathrm{Na}$ maioria dos casos, essas razões são, em grande parte, determináveis. $\mathrm{Na}$ Espanha, por exemplo, há uma grande classe de mendigos miseráveis e irrecuperáveis, e sua ociosidade, sujeira e mentira perturbam a própria alma do viajante. Qual o motivo da prevalência dessa classe degradada e de seus vícios? Uma dama da corte (Mme. D’Aunoy ) escreveu, em tempos idos, queixas piedosas da pobreza do soberano, da nobreza, do exército e das senhoras carentes que esperavam pela rainha. O soberano não podia dar a seus atendentes seus jantares; a nobreza derreteu seu prato e vendeu suas joias; os soldados estavam famintos na guarnição, de modo que os jovens desertaram, e os idosos e os inválidos desapareceram, na verdade morreram de fome. A senhora menciona com surpresa que uma quantidade particularmente grande de ouro e prata havia chegado das posses estrangeiras da Espanha naquele ano, e tenta explicar a miséria universal, dizendo que uma grande proporção dessas riquezas foi apropriada pelos comerciantes que forneciam o dinheiro. Espanhóis com as necessidades voltadas para o exterior, e ela fala disso como um mal. Ela é um exemplo de observadora não-filosófica — alguém em quem não se pode confiar — , muito menos para explicar a moral e os costumes das pessoas diante de seus olhos. O que diz um observador filosófico? ${ }^{9}$

Espanha e Portugal, países que possuem as minas, são, depois da Polônia, talvez os dois países mais pobres da Europa.

Seu comércio com suas colônias é realizado em seus próprios navios e é muito maior [do que seu comércio exterior], devido às grandes riquezas e extensão dessas colônias. Mas nunca introduziu quantidade considerável de manufatura para venda em nenhum desses países, de modo que a maior parte de ambos permanece inculta.

Diz-se que a proporção de ouro e prata voltada à produção anual da terra e do trabalho na Espanha é muito considerável, e que frequentemente você encontra uma profusão de prataria em casas onde não há nada mais que em outros países pudesse ser considerado adequado ou correspondente a esse tipo de magnificência. O preço baixo do ouro e da prata, ou, o que é a mesma coisa, o preço alto de todas as mercadorias, que é o efeito necessário dessa redundância dos metais preciosos, desencoraja a agricultura e a manufatura da Espanha e

\footnotetext{
${ }^{9}$ Martineau se refere a Adam Smith, em A riqueza das nações.
} 
de Portugal e permite que países estrangeiros forneçam-lhes uma variedade de produtos mal acabados, em quase todos os tipos de manufaturas, produzidos com uma quantidade menor de ouro e prata, o que atesta a capacidade que eles próprios teriam de criar ou fabricar em casa.

Quando se considera que na Espanha ouro e prata são chamados de riqueza, e que lá não há outra, que mal existem manufaturas e comércio, que a agricultura é desencorajada e que, portanto, há uma falta de ocupação para as classes mais baixas, pode-se muito bem concluir que as ordens superiores serão identificadas como preguiçosas, orgulhosas e pobres; as classes baixas ociosas em um estado de mendicância; e a parte mais virtuosa e feliz da população será a dos que se ocupam em cultivar o solo e a frente de atividades que são absolutamente necessárias nas cidades. É possível ver com os olhos da mente os grupos de uma elite intrigante, que não possuem negócios em suas propriedades para ocuparem seu tempo e pensamento; ou a multidão de mendigos famintos, aglomerando-se à porta de um convento para receber as esmolas diárias; ou os camponeses hospitaleiros e corteses, de quem um viajante ${ }^{10}$ diz:

Existe uma civilidade para com estranhos e um estilo fácil de comportamento familiar a essa classe da sociedade espanhola, muito distante das maneiras grosseiras e desajeitadas dos camponeses ingleses e alemães. Sua sobriedade e resistência ao cansaço são muito notáveis, e há uma constante alegria em seu comportamento, que logo causa boa impressão a um estranho em seu favor.

Eu ficaria feliz se pudesse, com justiça, dar uma imagem favorável das ordens mais altas da sociedade neste país, mas, talvez, quando consideramos sua educação miserável e seus hábitos precoces de indolência e dissipação, não devemos nos perguntar sobre o estado de desprezo e degradação a que estão reduzidos. Eu não estou utilizando a linguagem do preconceito, mas o resultado das observações que fiz, nas quais todos os observadores precisos entre nossos compatriotas concordaram comigo, dizendo que as ordens mais altas são tão inferiores às dos camponeses quanto as suas qualidades morais na opinião que lhes atribui.

Tudo isso pode ser inevitável em um país onde os meios de vida são passivamente derivados do exterior, e onde a honra e as recompensas da indústria bem sucedida estão confinadas a uma classe da comunidade. As minas devem assumir a culpa das falhas prevalecentes dos mendigos atrevidos e das grandezas da Espanha.

Para qualquer um que, de alguma maneira, tenha considerado os preceitos de um sistema social baseado na força física, ou no arranjo oposto que depende de um poder moral, não pode haver mistério algum no exterior que decorra de características morais

\footnotetext{
${ }^{10}$ A autora refere-se a William Jacob, de cujo livro — Viagens ao sul da Espanha, publicado em 1811 retirou a citação.
} 
prevalecentes entre os sujeitos de um dado sistema, e os vícios que existem entre eles, ainda que lamentados, serão julgados com indulgência. Peguemos o sistema feudal como exemplo inicial e, depois, o seu contrário. Um pouco de reflexão deixa claro quais virtudes e vícios possivelmente subsistirão sob as influências de cada um dos sistemas.

O barão mora em seu castelo, em um rochedo ou outra elevação, de onde pode ignorar seus domínios, ou onde seu ancestral ergueu a morada por motivos de segurança. Durante esse estágio da sociedade, há pouco refinamento e conforto domésticos. Os móveis são grosseiros, a biblioteca não é tentadora, e a luxuosa facilidade das cidades está fora de questão. Os prazeres do proprietário estão no exterior. Lá ele se dedica a esportes rudimentares e desfruta de seu luxo querido - o exercício do poder. Dentro da habitação, a esposa e seus assistentes passam a vida exercendo trabalhos manuais, brincando com os filhos e mantendo-os em ordem, em intermináveis conversas sobre o número reduzido de eventos que são capazes de notar, e em obediência e companheirismo com o padre. Enquanto o mestre está caçando ou reunindo seus criados para o banquete, as mulheres estão tecendo ou costurando, fofocando, confessando ou fazendo penitência; enquanto o padre estuda em seu apartamento, compartilha da alegria ou acalma os problemas da casa, e governa a mente dos nobres, garantindo a segurança da esposa. Fora de casa, existem criados, seja qual for a maneira de chamá-los. Suas pobres habitações estão amontoadas em volta do castelo do senhor; seus trechos de terra arável ficam mais próximos e os pastos mais distante, de modo que, pelo menos o suprimento de comida humana seja mais protegido de qualquer inimigo. Essas porções de terra são mantidas sob concessão de serviço, e, como os criados não têm propriedade, nem interesse em sua melhoria, e são, além disso, suscetíveis de serem afastados de suas lavouras a qualquer momento para prestar serviços militares ou outros, o solo produz colheitas sofríveis, e o gado magro não ornamenta bem as pastagens. As esposas dos camponeses são muitas vezes deixadas, sem qualquer aviso prévio, encarregadas de seus filhos desprotegidos, seminus e sem instrução, além de terem que cuidar do gado e do campo. - As festas do povo são nos dias santos e/ou quando o chefe retorna de uma guerra ou perseguição preeminente.

Agora, quais devem ser os costumes de um distrito como esse? E, pode-se acrescentar: de todo o país do qual faz parte? Pois, se existe um acordo feudal desse tipo, 
deve haver mais, e a sociedade é de fato composta por um certo número de agrupamentos de pessoas - de estabelecimentos como este. Não há necessidade de voltar alguns séculos para uma imagem original: ela existe em mais de um país da Europa agora.

Este tipo de sociedade é composto por apenas duas classes: aqueles que têm e aqueles que não têm nada. $\mathrm{O}$ chefe tem propriedade, algum conhecimento e grande poder. Com diferenças individuais, espera-se que os chefes sejam imperiosos, por sua liberdade e indulgência de vontade; corajosos, pela exposição ao trabalho e ao perigo; desdenhosos dos homens, por sua própria supremacia; supersticiosos, pela influência do padre em casa; pródigos, pela permanência de suas propriedades; vaidosos de posição e distinção pessoal, pela ausência de atividades desconectadas com o eu; e hospitaleiros, em parte pela mesma causa, e em parte porque sua própria hospitalidade é o único meio de satisfazer suas disposições sociais.

O clero será político, subserviente, estudioso ou indolente, bondoso, efeminado, com uma forte tendência ao orgulho espiritual e amor ao domínio espiritual. Será surpreendente também se não forem levados à infidelidade pela credulidade de seus pupilos.

As mulheres serão ignorantes e supersticiosas, por falta de instruções variadas; corajosas, pela presença frequente ou promessa de perigo; eficientes, pela pequena divisão do trabalho praticável na superintendência de uma família dessa natureza; dadas a fofocas e de temperamento incerto, pela mesmice de suas vidas; dedicadas a seus maridos e filhos, pela ausência de todos os outros objetos importantes; e vãs pelas realizações que têm, e por ignorar o que resta a ser alcançado.

Os criados devem ser ignorantes - fisicamente fortes e imponentes, talvez, mas infantis nas ideias e escravos na moral. A adoração deles é a idolatria — do chefe deles. As virtudes permitidas são a fidelidade, a diligência, o apego ao doméstico e a sobriedade. É difícil para eles enxergar outro universo possível. Suas falhas são todas aquelas compreendidas na palavra barbárie.

Essas características podem ser estendidas às divisões da nação que correspondem às da família: pois o soberano é apenas um chefe feudal superior, seus nobres são um tipo mais exaltado de servos; e aqueles que são senhores em casa tornam-se escravos na corte. Sob esse sistema, quem seria tão resistente a tratar a brutalidade de um servo, a astúcia 
de um padre, o preconceito de uma dama e a imperiosidade de um senhor, como sendo nada mais do que os resultados — inevitáveis e tristes — do estado da sociedade?

O feudalismo baseia-se na força física e, portanto, tem uma relação apenas com o passado. O direito começa no poder, e todas as relações sociais dos homens se originaram na superioridade física. As ideias mais predominantes do período feudal surgem do passado, o que há mais tempo foi sendo considerado honrado, e a compreensão dos homens, não exercitada pelo aprendizado, e indisciplinada pela sociedade e pela ação política, recai sobre precedentes e repousa ali. Os gostos e até as paixões do período feudal têm uma relação com a antiguidade. A ambição, por mais prospectiva que seja em sua natureza, tem, nesse caso, um forte caráter retrospectivo. A glória que o descendente deriva de seus pais, ele sacrifica-se para transmitir. O passado é tudo: o futuro, exceto na medida em que se assemelhe ao passado, não é nada.

Ocorria o mesmo, até recentemente, embora com modificações, em relação às ideias, gostos e paixões predominantes do mundo civilizado. O estado oposto da sociedade, que começou a ser realizado, enseja ideias prevalentes e, portanto, virtudes e vícios prevalentes, de caráter oposto.

Na medida que o comércio expande, e outras profissões além da clerical surgem, o comércio se torna lucrativo, as cidades aumentam de importância, a comunicação melhora, vilas se tornam cidades e aldeias vilas, e os assuntos das comunidades centrais se espalham pelo perímetro. Quando as classes mais baixas crescem, os chefes perdem grande parte de sua importância, o valor dos homens por suas qualificações intrínsecas é descoberto, e esses homens assumem a liderança para administrar os assuntos dos cidadãos associados a eles. Em vez de tudo ser feito por meio de ordens emitidas de um poder central - ordens que executam uma vontade imperiosa e trazem de volta uma indubitável obediência - os assuntos sociais começam a ser gerenciados pelas cabeças e mãos das partes imediatamente interessadas. O autogoverno nos assuntos municipais ocorre, e, tendo ocorrido sob qualquer conjunto de circunstâncias, parece provável que seja empregado dentro de uma faixa cada vez mais ampla, até que todo o governo da comunidade tenha esse caráter. Os Estados Unidos são o exemplo mais notável do mundo reverso do sistema feudal — seus princípios, métodos, virtudes e vícios. Na medida em que os americanos revertem, em ideias e gostos, a direção para o passado, isso pode ser 
atribuído à transição que ainda não está aperfeiçoada — pela geração que organizou a república e que foi educada em meio aos restos do feudalismo. Ainda existem americanos que se gabam de ancestrais elevados na ordem de nascimento, e não por mérito, que, ao falar de posição, têm em mente ideias de nascimento e cujos gostos estão no passado. Este é o caso quando a literatura do mundo respira o espírito de épocas anteriores e suaviza a transição para um estado social oposto. Uma nova literatura, novos modos de pensamento, surgem diariamente, apontando cada vez mais para o futuro. Já temos registros do estado imediato das mentes e fortunas dos homens e das comunidades, e não são poucas as especulações que se estendem para o futuro. A cada ano é admitido mais amplamente que o poder moral é mais nobre que a força física, há mais seriedade nas conferências das nações e menos propensão à guerra. As criações mais altas da própria literatura, embora produzidas há muito tempo, agora são descobertas como tendo uma relação mais próxima com o futuro do que com o passado. Elas são fruto do tempo, atravessando todas as suas mudanças. Enquanto pilares de luz nas regiões sombrias da antiguidade, elas passam pela madrugada e ainda estão diante de nós, lançando suas sombras aos nossos pés como guias para o futuro deslumbrante. Entre eles, destaca-se o Livro que nunca teve caráter retrospectivo. Nunca sancionou força física, orgulho de ancestralidade, valor, influência ou qualquer outro orgulho. Nunca sancionou a divisão social arbitrária. Nunca elogiou as virtudes do feudalismo em sua desconexão com outras virtudes; nunca poupou as falhas do feudalismo, por serem o produto necessário das circunstâncias feudais; nem agora elogia e tolera as virtudes e os vícios desenvolvidos pela democracia. Este guia nunca descansou. É um avanço de todas as democracias existentes, como uma vez foi de todos os despotismos. O fato é que, embora todas as manifestações de força intelectual e moral eminente tenham uma qualidade imperecível, este livro supremo não tem apenas um frescor imortal, pois não tem relação com o tempo: — para ele "um dia é como mil anos; e mil anos como um dia ".

Quais são as virtudes e falhas prevalecentes que devem ser procuradas no futuro - ou nos países que representam algo do futuro, pois outros oferecem uma imagem enfraquecida do passado? Que ponderações seria necessário o viajante fazer na América? Quase precisamente o contrário do que ele teria que fazer na Rússia. 
O luxo interno sucedeu o esporte externo: as artes mecânicas florescem da elevação das classes inferiores, e as valentias estão fora de moda. A consequência disso é que o viajante vê ostentação de luxo pessoal em vez de séquito/comitiva. No curso da transição para o tempo em que o mérito constituirá a mais alta reivindicação de classificação, a riqueza sucederá ao nascer: mas, mesmo assim, as reivindicações de riqueza cederão antes às do intelecto. $\mathrm{O}$ autor popular tem mais observância do que o milionário nos Estados Unidos. Isso é honroso e rende a promessa de uma graduação ainda melhor na sociedade. Onde a força moral é reconhecida como a força motriz da sociedade, parece seguir que a condição da mulher deve ser elevada; que novas atividades lhe serão abertas, e uma disciplina mais ampla e mais forte será concedida a seus poderes. Não é assim na América, mas isso se deve à interferência de outras circunstâncias no pleno funcionamento dos princípios democráticos. A ausência de uma vontade aristocrática ou soberana impele os homens a encontrar outra vontade para repousar sua fraqueza individual, e com ela empregar sua veneração humana. A vontade da maioria se torna seu refúgio, uma lei não escrita. Os poucos de espírito livre resistem a essa vontade, quando se opõe a deles, e os muitos servos se submetem. Isto é considerado a culpa mais evidente dos americanos. Sua cautelosa subserviência à opinião pública — sua deficiência de independência moral - é o pecado de sua sociedade. Novamente, a igualdade social pela qual toda a vida é aberta a todos em uma república democrática, na qual todo homem que tem poder em si pode alcançar tudo aquilo que esse poder tem de requisito, não pode deixar de aumentar a importância de cada uma de suas qualidades aos olhos de todos, e a consequência é o respeito e deferência mútuos e também uma ajuda mútua, que são em si mesmos virtudes de alta ordem, e preparativos para lidar com os outros. Nestes, os americanos são exercitados e realizados em um grau que nunca foi alcançado em nenhum outro país. Essa classe de virtudes constitui sua honra distintiva, sua graça imponente na companhia das nações. Atividade e engenhosidade são uma questão de curso onde o lote de cada homem está em suas próprias mãos. A hospitalidade e a caridade ostensivas podem, em algumas democracias, provavelmente definhar, mas os americanos têm a riqueza de um país jovem, e o calor de uma existência nacional jovem, como estímulo e garantia de liberalidade pecuniária de todo tipo. Vaidade popular e subserviência de representantes políticos são os principais perigos que ainda estão por enfrentar, e provavelmente não haverá república por muito tempo em que não sejam encontradas as 
formas de vícios prevalecentes. Se, sob um sistema feudal, houver um exercício saudável de reverência no culto aos ancestrais, existe, sob o sistema oposto, um impulso não menos salutar e perpétuo à generosidade no cuidado com a posteridade. A primeira tem sido, sem dúvida, uma influência benigna, temperando a aspereza e a violência do despotismo; o outro provará uma força elevadora, içando os homens acima do egoísmo pessoal e da subserviência mútua, que são os perigos que assolam os iguais que se unem para governar por sua vontade comum.

Qualquer que seja sua filosofia de caráter individual, o observador reflexivo não pode viajar, com a mente acordada, sem admitir que não há dúvida de que o caráter nacional seja formado, ou amplamente influenciado, pelas circunstâncias gigantescas que, não sendo ela produto de nenhuma mente individual, são diretamente atribuíveis ao grande Governante Moral da raça humana. Todo ato sucessivo de pesquisa ou viagem o impressionará cada vez mais profundamente com essa verdade, que, em prol de sua própria paz e liberalidade, seria bom que ele mantivesse esse embasamento desde o início. Ele não visitará pessoas com qualquer amargura de censura por participar de falhas prevalecentes. Ele considerará virtudes e graças sociais como honra derramadas sobre todos que são ofuscados, dos mais altos aos mais humildes; enquanto ele não estiver disposto a ceder ao desprezo, ou qualquer outra coisa que não seja uma compaixão leve, por qualquer depravação ou deformidade social que, sendo o resultado claro das circunstâncias, e ela própria uma circunstância, possa ser considerada tão claramente destinada a ser remediada, quanto a sabedoria dela associada, a do homem individual, que cresce99 com o seu crescimento e se fortalece com a sua força.

\section{Traduzido de}

MARTINEAU, Harriet. Philosophical requisites. In: MARTINEAU, Harriet. How to observe morals and manners. London: Charles Knight and Co., 1838, p. 11-39. E-book. Disponível em: http://www.gutenberg.org/files/33944/33944-h/33944-h.htm\#piii. Acesso em: 28/02/20.

Recebido em: 09/05/20.

Aceito em: 18/05/20. 